DIW BERLIN

Discussion

Papers
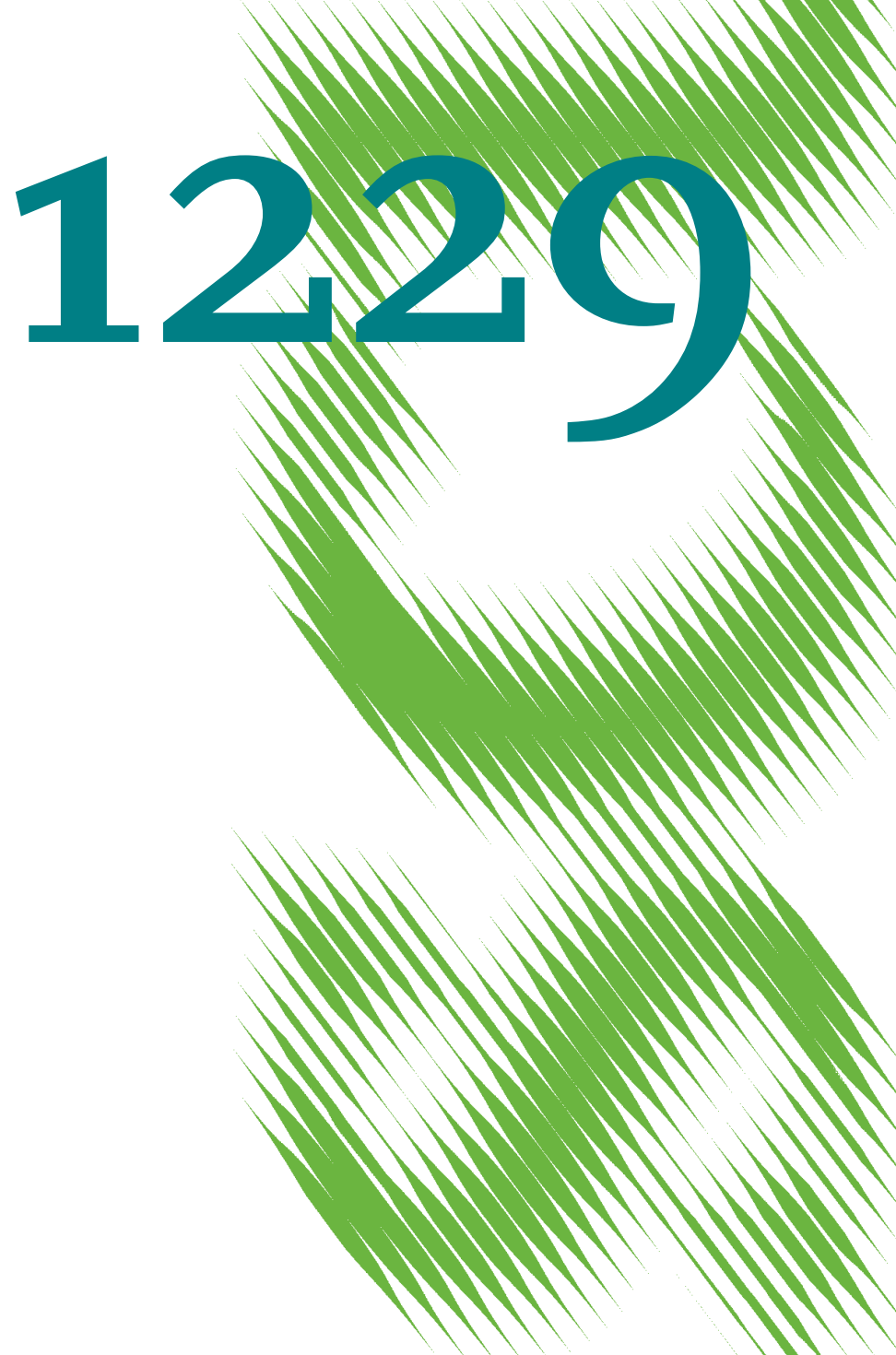

Knowledge, Location, and Internationalization: Empirical Evidence for Manufacturing SMEs 
Opinions expressed in this paper are those of the author(s) and do not necessarily reflect views of the institute.

IMPRESSUM

(C) DIW Berlin, 2012

DIW Berlin

German Institute for Economic Research

Mohrenstr. 58

10117 Berlin

Tel. $+49(30) 89789-0$

Fax +49 (30) $89789-200$

http://www.diw.de

ISSN print edition $1433-0210$

ISSN electronic edition 1619-4535

Papers can be downloaded free of charge from the DIW Berlin website:

http://www.diw.de/discussionpapers

Discussion Papers of DIW Berlin are indexed in RePEc and SSRN:

http://ideas.repec.org/s/diw/diwwpp.html

http://www.ssrn.com/link/DIW-Berlin-German-Inst-Econ-Res.html 


\title{
Knowledge, Location, and Internationalization: Empirical Evidence for Manufacturing SMEs
}

\author{
Anna Lejpras* \\ German Institute for Economic Research (DIW Berlin), Berlin, Germany
}

\begin{abstract}
This paper investigates the links between locational conditions, innovative capabilities and internationalization of manufacturing SMEs. Two modes of foreign market servicing are explored: exporting activity and relocating of selected business activities abroad. The empirical analysis employs two probit models based on survey of about 3,000 firms. The results reveal that the outputs of SMEs' innovative activities-i.e., product innovations and patent applications-enhance exporting propensity as expected. Nevertheless, the input-side indicator-R\&D intensity-appears to exert no impact. Further, the locational factor proximity to research institutions promotes SMEs' engagement in exporting. Regarding the determinants of selective relocations abroad, the findings show that SMEs with a high degree of R\&D are less likely to separate production from other operations and relocate it abroad. Moreover, manufacturing SMEs assessing the proximity to research facilities, as well as support from various regional authorities and other bodies as important and good-quality locational conditions, exhibit a significantly lower likelihood to relocate selected activities abroad. Indeed, emphasizing the role of institutional setting in firm activity, our findings coincide in this respect with the previous literature focused on innovative milieu, learning regions and regional innovation systems.
\end{abstract}

Keywords: export, innovation, location, manufacturing SMEs, selective relocation abroad

JEL-classification: R30, O30, M16, L25

*Anna Lejpras, DIW Berlin, 10108 Berlin, Germany, tel. +49 (0)30 89789 -348, fax -103, alejpras@diw.de

Acknowledgements: I give my special thanks to Heike Belitz and Alexander Eickelpasch for their helpful comments and suggestions. Furthermore, I gratefully acknowledge the suggestions and comments by the attendees of the 37th Annual Conference of EARIE in Istanbul 2010, the Warsaw International Economic Meeting in Warsaw 2010 and the 12th Uddevalla Symposium in Bari in 2009. The usual disclaimer applies. 


\section{Introduction}

Globalization and the rapid progress of information and communication technologies triggered the process of firm internationalization and the inter-country redistribution of economic activity, on the one hand, and the emergence of the knowledge-based economy, on the other hand (Amin and Thrift 1994; Audretsch 2000; Crouch and Trigilia 2001; Sorenson and Baum 2003; Storper 1995a). Within this context, some scholars prophesied the 'death of distance' and proclaimed a diminishing importance of location (Cairncross 1997; Gray 1998). Yet, a wider body of research argues that location still matters due to the role of the 'proximity factor' in the processes of creation and transfer of knowledge, especially tacit knowledge (e.g., Audretsch 2000; Aydalot and Keeble 1988; Campagni 1991; Fujita et al. 2001; Lundvall 1992; Storper 1995a, 1995b).

Over the last decades, an ever-increasing number of SMEs, particularly those in the manufacturing sector, are engaging in international activity (Acs et al. 1997; Knight 2001; Lo et al. 2007; OECD 1997, 2008). Despite the growing literature in this field, there is little effort to empirically investigate the relationships between the location-specific advantages, innovation activity (which refers to the conversion of knowledge into new products, services and processes) and SMEs' internationalization.

Previous studies demonstrate the superior export propensity and export intensity of firms located in industrial districts and/or clusters-i.e., regions that constitute the basis of specific and non-transferable resources and capabilities, and that provide favourable conditions enabling firms to exchange relations and knowledge efficiently and, thus, to discover and sustain competitive advantages - compared to those located outside (e.g., Becchetti and Rossi 2000; Belso-Martínez 2006; Enright 1998; Swann et al. 1998). Here, the 'district effect' is captured mainly via a very simplistic measure (a dummy variable). Due to the nature of this approach, it is impossible to include all the ways that the local environment 
can influence firm internationalization into consideration. In other words, these studies fail to investigate how various aspects and/or attributes of location shape a firm's international behaviour. Further, there is some research exploring the link between firm innovativenessmeasured either by firm R\&D intensity or product innovations - and its engagement in exporting. As to product innovations, existing papers present a consistent finding of a positive relationship between firm innovative capabilities and export behaviour (e.g., Bleaney and Wakelin 2002; Grossman and Helpman 1996; Roper and Love 2002). However, the results of those applying R\&D intensity as an indicator are not so straightforward—some scholars show a positive effect (e.g., Kirbach and Schmiedeberg 2008), while others find no impact of R\&D on exporting (Becchetti and Rossi 2000; Schlegelmilch and Cook 1988). Finally, focusing in the first instance on exporting activity, the extant empirical literature neglects to model the impact of SMEs' innovativeness and location on the choice of other forms of foreign market presence. Thus, this paper aims to shed some light on these issues.

The main goal of this study is to offer empirical evidence for the influence of localization advantages and SMEs' innovativeness on their internationalization. Thereby, two considerably different modes of foreign market servicing are taken into account: (1) a widely examined mode, exporting activity; and (2) one that is scantly modelled, the relocation of selected business operations abroad by independent SMEs. It is important to note that here the impact of location attractiveness is resolved into separate effects of various locational characteristics, which, according to the literature, are related to creating innovation-based competitive advantage and, thus, should facilitate firm internationalization. Such locational conditions are, for instance, the availability of skilled labour in the region or close proximity to a university. Furthermore, to account for the complexity of the phenomenon of firm innovativeness, we include several (both input and output-oriented) indicators of innovativeness like R\&D intensity, product innovations, and patent applications. Concretely, the paper aims to answer the following research questions: (1) Do locational conditions have 
an impact on firm internationalization, and, if so, how does the effect of various locational attributes vary with respect to different forms of foreign activity? and (2) how do R\&D intensity and the outputs of innovation activities affect SMEs' internationalization?

This paper is structured as follows: after examining some of the relevant internationalization theories and the possible relationships of these theories with the role of firm location and its innovative capabilities in its foreign activity, the relevant empirical literature is discussed and our hypotheses are presented. Section 3 gives information on the methodology by describing the data and the econometric model. Section 4 presents the results of the descriptive analysis and the model estimations. In Section 5, we discuss our main findings. Section 6 concludes with the implications and limitations of our study.

\section{Conceptual framework}

\section{Context: globalization, knowledge, and location}

The ever-increasing globalization of production and the rapid technological change are challenging the comparative advantages of countries and regions and, thus, also strongly influence the sources of firm competitive advantage. Exposed to ever-increasing competitive pressure from foreign lower-cost locations, companies in developed, high-cost countries and/or regions are implementing several strategies in order to survive, sustain and/or improve competitiveness: (1) reducing production costs and product selling prices sufficiently; (2) increasing productivity and efficiency by developing and/or adopting new, innovative technologies and production processes; (3) relocating production or other activities out of high-cost locations into low-cost locations; and (4) capturing and assuring the shares in global and national markets by means of introducing product innovations (i.e., developing and launching new products and services, as well as improving the quality and features of existing ones). Hence, globalization, coupled with the rapid technological change, triggers a process of firm internationalization and the inter-country redistribution of firms, on the one hand, and the 
emergence of the knowledge-based economy, on the other hand (Amin and Thrift 1994; Audretsch 2000; Crouch and Trigilia 2001; Sorenson and Baum 2003; Storper 1995a).

In the face of the extensive restructuring taking place in the spatial allocation of economic activity (and implicitly also knowledge) across countries and regions, combined with the quick progress in information and communication technologies (ICT), some scholars prophesied the 'death of distance' and proclaimed the diminishing importance of location (Cairncross 1997; Gray 1998). This is because the marginal costs of transmitting information across geographical space have been drastically reduced. A wider body of literature, however, argues that location still matters since sharing of knowledge, which, in turn, is a crucial input factor in the economy, occurs less efficiently as distance increases (Audretsch 2000; Fujita et al. 2001; Martin and Sunley 2002). The seeming contradiction of these notions can be explained in terms of differences between knowledge and information.

Unlike transmitting information, the creation and sharing of knowledge, especially of tacit knowledge, requires both frequent and intensive communication and interactions, which are characterized by highly non-standard, explorative, ambiguous and scarcely codifiable processes. These activities are activated and performed more effectively face-to-face and, consequently, by geographical, personal and cognitive proximity (Aydalot and Keeble 1988; Campagni 1991; Cooke 2002; Gordon and McCann 2000; Granovetter 1992; Huggins and Johnston 2010; Storper 1995b; Tolstoy 2010).

Thus, even in the era of globalization and digitalization, location still plays an important role in the process of developing the innovation-based competitive advantage of firms and their internationalization practices (Cooke 2002; Krugman 1991; Lundvall 1992; Porter 1990; Storper 1995a, 1995b; Vázquez-Barquero 2002).

\section{SMEs' internationalization, innovativeness and location: theoretical considerations}

Although the phenomenon of globalization is chiefly associated with the activities of large multinational corporations, SMEs, especially those from the manufacturing sector, are 
engaging in international activity to an ever-increasing extent (Acs et al. 1997; Knight 2001; Lo et al. 2007; OECD 1997, 2008). With this expansion, the literature on the involvement of SMEs in foreign markets is significantly expanding (e.g., Barringer and Greening 1998; Fernández-Ortiz and Lombardo 2009; Hollenstein 2005; McDougall and Oviatt 1997; Oviatt and McDougall 1997; Wolff and Pett 2000; Zahra and George 2002). This research concentrates primarily on the process of internationalization itself and, thereby, investigates characteristics — either firm-related or managerial—of SMEs that decided to act internationally; the reasons and motivation for international expansion; the entry modes SMEs adopted and the countries entered; as well as, the differences between firms operating in domestic markets only and those selling products abroad.

In view of the obvious complexity of the firm internationalization process, the literature offers several theoretical approaches explaining this pattern, such as internalization approach and the eclectic paradigm, stage models or network perspective. Even though, overall, the existing theories provide many interesting and valuable insights into this multifarious and multi-dimensional phenomenon, the resulting picture is fragmented (Coviello and McAuley 1999; Daniels 1991; O’Farrell et al. 1998). Indeed, each places the emphasis on fairly different aspects of the internationalization pattern. Moreover, given the importance of knowledge and, thus, of the 'proximity factor' in the economy, all of these theoretical approaches pay surprisingly little attention to justifying the location-specific advantages and benefits of firm R\&D and innovation activity in connection with its engagement in foreign markets (Amiti 1998; Dunning 1998; Molina 2002).

For instance, the internalization theory argues that firms choose the mode of market servicing for which overall transaction costs are minimized (Anderson and Gatignon 1986; Buckley and Casson 1976; Buckley 1988; Rugman 1981; Hennart 1988, 1991; Williamson 1975, 1979). Accordingly, because of imperfections in goods and factor markets, firms offering knowledge-intensive products will favour high-control modes of foreign market 
entry—-through establishment of a hierarchically structured organization, i.e., FDI—in order to reduce the risk of knowledge advantage. Conversely, standardized and unsophisticated products can be distributed more efficiently in lower-control modes - through nonequity or contractual agreements, e.g., licensing or exporting. In addition to these internalizing (I) advantages, the eclectic (OLI) paradigm of Dunning highlights two other types of advantages that influence the international engagement of a firm, namely ownership-specific (O) and location-specific (L) advantages (Dunning 1981, 1988). O-advantages refer to unique firmrelated characteristics and capabilities that make a firm superior to its foreign competitors; these encompass not just tangible assets (such as workforce, capital, and property rights) but also intangible ones (e.g., managerial and entrepreneurial skills, noncodifiable knowledge embodied in human capital experience, etc.). L-advantages involve potential benefits of firm activity in a particular foreign location due to locational characteristics including resource endowments and markets, transport and communication costs, infrastructure, barriers to trade, business and cultural environment, political and institutional framework, and so forth.

Another well-known approach - the stage model (also known as the Uppsala model or U-model)- examines foreign market expansion in terms of hypothetical development stages (Johanson and Vahlne 1977, 1990; Johanson and Wiedersheim-Paul 1975). The main proposition of the stage model is that firm internationalization occurs incrementally and gradually due to the lack of knowledge, especially experiential knowledge, and uncertainty. The model suggests that firms initially engage in psychically and, thus, often also spatially close foreign markets (i.e., those that are not so very different from the home market) through low-risk, indirect exporting approaches. Over time, based on experience gained this way, the firm will expand into more distant markets through higher control modalities.

A third and newer school of internationalization research, referred to as the network perspective, recognizes that foreign market development does not solely depend on firmrelated advantage, but also on networking activities and strategic alliances (Bell 1995; 
Blankenburg and Johanson 1992; Cunningham and Culligan 1991; Johanson and Mattsson 1988, 1992; Johanson and Vahlne 1990, 1992). The portfolio of exchange relationships includes connections to a variety of partners, such as individuals, business units, and public agencies. The network perspective approach argues that links to partners located in the hostcountry and/or servicing overseas markets, are of great relevance to a firm's internationalization. This is because it is via collaboration and networking with foreign partners that firms gain the capabilities and knowledge about country-related resource endowments, markets, infrastructure, and barriers to trade needed for expansion.

Summing up, although the existing theories of firm internationalization appear to refer to the role of firm innovativeness and localization advantages in its foreign engagement, these are addressed only roughly. In fact, these theories capture the significance of firm innovative capabilities in its international activity only via broadly understood firm-related characteristics, such as human capital resources and/or knowledge and experience accumulated within the firm. Furthermore, when discussing the spatial aspects of the internationalization process, these approaches focus mostly on the attributes of and/or benefits from the foreign location, as well as, highlight the importance of collaboration and networking with primarily foreign partners. In this respect, thus, these neglect to analyse the role of the local business environment in firm activities and internationalization processes (Belso-Martínez 2006; Molina 2002).

Therefore, the main goal of this paper is to shed some light on the role of firm innovativeness and the attractiveness of location on its international activities. Specifically, this study empirically investigates how SMEs' R\&D and innovation activities, as well as the attributes of its location affects the choice between two different internationalization modes - exporting activity and relocation of production or other operations abroad. Our motivation behind the selection of the two forms of foreign activity and the corresponding hypotheses being under examination are presented below. 


\section{Empirical evidence and hypotheses}

Two internationalization modes: exporting vs. selective relocation broad

As briefly pictured, firm internationalization is, indeed, a complex phenomenon and multifaceted concept. From the viewpoint of a firm, the most important decision regarding the international expansion is how to enter foreign markets, as the way the firm enters can significantly influence its further activities and development (Benito and Welch 1994; Doole and Lowe 1999; Ruzzier et al. 2007). ${ }^{1}$ Moreover, since regional outcome can be derived from the activities and performance of the various economic actors operating within the region (Britton 2004; Lejpras and Stephan 2011; Oerlemans et al. 2001; Rees and Stafford 1986), the chosen mode of international engagement by firms can clearly affect the development and performance of regions, as well (e.g., Biggiero 2006; deMartino et al. 2006).

To analyse the relationships between localization advantages, firm innovativeness and its internationalization, this paper takes two modes of foreign market servicing into consideration: exporting activity and the relocation of production or other operations abroad (also called selective relocation). Since the extant literature on firm internationalization rarely examines relocation abroad as a form of international activity, we review some basic facts about this issue in the following: Relocation strategies refer to transferring firm activities among regions and countries (Biggiero 2006; Sammarra 2005). Selective relocation addresses the capability of firms to select operations among the phases of production cycle or the functional activities - but only those that allow firms to achieve substantial and long-lasting benefits - and shift these activities to foreign locations. More strategic operations and

\footnotetext{
${ }^{1}$ Thereby, there is no ideal strategy of foreign market involvement: Different modes of international activity can be implemented by different firms entering the same market and/or by the same firm in different markets. Moreover, due to the dynamic nature of internationalization, the modes of entry and operations are evolving as well. Accordingly, scholars have proposed different classification schemes of international activity. For instance, Root (1994) distinguishes between export entry modes, contractual entry modes and investment entry modes, while Punnett and Ricks (1992) classifies exporting, international networking and foreign investments based on the criteria of ownership, i.e., as no-foreign ownership, joint ventures and sole ownership types of foreign engagement, respectively.
} 
activities, especially the most value added and knowledge-intensive ones, persist in the source and/or home location. Beyond selective relocations, Sammarra (2005) also distinguishes replicative relocations; those, however, are out of the focus of this paper. ${ }^{2}$

These two modes of internationalization - exporting and selective relocation abroadmight have a very different impact on both firm activity and regional development. Exporting behaviour is perhaps the most commonly examined form of foreign market servicing. In fact, overseas sales and their increase refer to and/or have been repeatedly used as indicators of economic performance and growth at both the firm and regional levels (e.g., Belso-Martínez 2006; Cooper and Kleinschmidt 1985; Keeble et al. 1998). Another type of international activity under investigation in this paper-relocation of production or other operations abroad - is scantly modelled, mostly due to the scarcity of suitable data. This internationalization mode is far more controversial than exporting in terms of possibly different effects on the performance of firm and regions. Although shifting some business operations to low-cost location might enhance firm competitiveness and productivity, it is possible, at the same time, that it may damage regional economic development due to both potential job losses as well as the outflow of competencies and expertise from the home/source region (Alberti 2006; Biggiero 2006; Molina-Morales and Martínez-Fernández 2006; Sammarra and Belussi 2006).

\section{Localization advantages and SMEs' internationalization}

There is a large and growing body of theoretical and empirical research on the spatial allocation of economic activity. Traditionally, clusters or industrial districts (IDs) are acknowledged as an organisational model that enables firms to discover and develop

\footnotetext{
${ }^{2}$ Replicative relocation implies the move of all firm operations and activities from its source location to a foreign destination location (Biggiero 2006, Sammarra 2005). Firms implementing the strategy of replicative relocation tend to be clearly oriented to and/or favoured of the localization advantages from the destination location. Hence, it appears to be somehow pointless to inquire the effects of the attractiveness of the source location on adopting the replicative relocation strategy by firms. As a result, this paper takes only selective relocations abroad into consideration.
} 
competitive advantages. Main characteristics of ID regions are the existence of strong networks, collaboration promoting faster dissemination of new ideas, experiences and knowhow due to geographical proximity, homogenous communities and institutions, common manufacturing traditions, and easier access to complementary services or capabilities, to name a few (Becattini 1990; Cooke 2002; Cooke and Morgan 1998; Gordon and McCann 2000; Marshall 1920; Porter 1990, Ramírez-Pasillas 2010; Staber 2009; Storper 1995a). The localization benefits of this kind appear to be of special significance for SMEs' national and international competitiveness. This is because SMEs have less resource capacity in terms of financing, staffing and knowledge when compared to large MNEs. In addition, SMEs are less able to profit from the inter-regional or international division of labour. Thus, SME activity may depend heavily on quality of its local environment (e.g., Acs et al. 1997; Brunninge et al. 2007; Hollenstein 2005; Keeble et al. 1998; Kuo and Li 2003).

Previous empirical studies demonstrate the superior international performanceespecially exporting performance — of firms located in advantageous regions and/or IDs. For example, using Sforzi indicator for defining ID firms among the sample of about 4,000 Italian companies, Becchetti and Rossi (2000) show a positive and direct relationship between geographical agglomeration and export behaviour. Moreover, they find that benefits to export participation and export intensity from being located in an ID are greater for small firms and for firms affiliated with traditional and specialized sectors. Based on information from 285 Spanish SMEs, Belso-Martínez (2006) finds similar results: Locating in an ID area facilitates export activity and export intensity. He also shows that client networks and competitor networks (frequently found in industrial districts) appear to influence positively SMEs' export performance. Additionally, some scholars find that firms located outside IDs do not capture the localization benefits to the same extent as firms located inside the districts (Enright 1998; Swann et al. 1998). 
Overall, however, it is important to note that the aforementioned studies capture the impact of localization advantages on firm's international involvement through a dichotomous variable for being located in a cluster or industrial district only. Obviously, such a simplifying approach cannot account for various aspects and/or characteristics of location that might influence firm internationalization (Paniccia 2002). Moreover, by focusing on the 'industrial district' effect, these studies to not take into consideration that the more disadvantaged and/or lower-rated regions might still have some factor conditions more favourable for firm business operations.

Indeed, the location can influence firm activity in many ways. Thus, the impact of the location on firm economic activity can be divided into the separate effects of various locational conditions (Asheim and Gertler 2005; Cooke and Morgan 1998; Gordon 1991). Access to knowledge and technology from various sources — such as skilled labour, universities, research institutes, collaboration, and networking — are argued to be fundamental factors in the knowledge economy (e.g., Audretsch and Feldman 1996; Beise and Stahl 1999; Feldman 1999; Jensen and Thursby 2001; Lockett et al. 2009; Mowery and Ziedonis 2001; Rees and Staffors 1986; Stöhr 1986; Zucker et al. 1998). The literature also highlights the role of the institutional setting — including local authorities and other regional organizations — for firm development and performance. This role includes a wide range of support: financial (e.g., seed capital, R\&D grants, network-building grants), incubation programmes, commercial advice, and consultancy (e.g., Cooke 2002; Longhi 1999; Meyer 2003; Rocha et al. 2009; Vázquez-Barquero 2002). Finally, the importance of the transportation infrastructure for firm activity is stressed ever since the early stages of the theory of location (e.g., Lösch 1938; Rees and Stafford 1986; Weber 1929).

We expect that firm location attractiveness - measured in terms of various locational conditions - should affect differently the likelihood of adopting both of the SME internationalization strategies considered in this paper. On the one hand, in accordance with 
the literature mentioned above, we hypothesize that favourable locational conditions should facilitate exporting activity by SMEs. On the other hand, however, we propose that SMEs with a high-quality local environment are less willing to move activities abroad than those operating in less-advantageous and/or unfavourable locational conditions. Hence, the following hypotheses are formulated:

Hypothesis 1a Favourable locational conditions increase the propensity of an SME to export. Hypothesis 1 b Favourable locational conditions decrease the propensity of an SME to relocate selected business operations abroad.

\section{Firm innovativeness and internationalization}

Innovative capabilities — including R\&D and innovation activities — are regarded as major drivers of achieving and sustaining both national and international competitiveness as well as firm performance (e.g., Audretsch 2000; Martin and Sunley 2002; Porter 1990). There is a fairly large literature investigating the link between firm innovativeness and its engagement in foreign markets. Many of those papers use R\&D intensity as a measure of the firm's innovative ability, but some focus on product innovations (i.e., the introduction of new products or improvements to existing ones). The former indicator of firm innovativeness refers apparently to the input side of the innovation process; the latter one is an outputoriented measure.

As for product innovations, existing papers present a consistent finding of the positive relationship between firm innovativeness and internationalization (e.g., Becchetti and Rossi 2000; Bleaney and Wakelin 2002; Grossman and Helpman 1996; Kirbach and Schmiedeberg 2008; Roper and Love 2002). However, the results of those applying R\&D intensity as an indicator of firm innovative capabilities are not so straightforward: For example, for the German manufacturing firms, Kirbach and Schmiedeberg (2008) find a strong positive, nonlinear relationship between $R \& D$ and both export probability and export share. Using data on Japanese firms, Ito and Pucik (1993) show that export sales volume is positively associated 
with $R \& D$ expenditure and firm size, but that a firm's export ratio is not related to the R\&D intensity when firm size is included in the model. Based on firm level panel data for Spanish manufacturing, Barrios et al. (2002) demonstrate that R\&D intensity stimulates firms to export more, but apparently it does not influence the decision to, or not to, engage in exporting activity. Finally, some scholars find that R\&D has no impact on export activity and intensity (e.g., Becchetti and Rossi 2000; Schlegelmilch and Cook 1988).

Accordingly, we argue that various aspects and/or measures of firm innovative capabilities might affect firm internationalization in different ways. In line with the existing literature, we propose that the outcome from the innovation activities, in the form of product innovations or issuing licences, relates positively to the foreign engagement of a firm, irrespective of the form of international involvement.

Nonetheless, we think that R\&D activity may have different impacts on the decision to export versus whether or not to relocate selected business operations abroad. On the one hand, even though the empirical evidence on the relationship between $R \& D$ and exporting appears to be ambiguous, one could expect that these business activities should be positively related to each other. This is because firm R\&D activity is positively associated with its ability to introduce innovations and, hence, to strengthen its position in domestic and international markets (e.g., Brouwer and Kleinknecht 1996; Griliches 1984; Porter 1990).

On the other hand, however, one should keep in mind that knowledge and innovation creation processes tend to be local phenomena (e.g., Audretsch 2000; Aydalot and Keeble 1988; Biggiero 2006; Campagni 1991; Cooke 2002; Gordon and McCann 2000, Keeble et al. 1998; Storper 1995b). In fact, obviously, it is the R\&D activity-rather than activities related to the output of the innovation process - that is dependent upon and embedded within local milieu, including universities, public and private research laboratories, training and venture capital organizations, as well as regional authorities. Indeed, each local milieu incorporates unique economic, sociological, political and institutional factors that are difficult or even 
impossible to replicate elsewhere. Moreover, as noted earlier, R\&D (as are other strategic activities characterized with a high content of tacit knowledge) benefits more from long-term relationships promoted by extensive face-to-face interactions mutual learning and feedback processes, as well as joint problem-solving, which, in turn, reduces monitoring and transaction costs. Therefore, we expect that SMEs engaging in R\&D are less likely to separate the functional operations and relocate selected ones abroad than firms with no R\&D. Consequently, the following hypotheses are expected to hold: Hypothesis 2a Innovative output-e.g., product innovations or patent applications-is positively related to the propensity of both exporting and relocating selected business operations abroad by SMEs.

Hypothesis $2 b$ Innovative input-i.e., $R \& D$ intensity-increases the propensity of exporting but decreases the propensity of relocating selected business operations abroad by SMEs.

\section{Methodology}

\section{Data}

The empirical analysis of this paper uses firm-level data collected by the German Institute for Economic Research (DIW Berlin) as part of a large survey entitled "Current Situation and Outlook of East German Firms." This survey was sent to 30,000 firms from the manufacturing and service sectors in East Germany in 2004; the response rate was approximately 20 per cent. The questionnaire consisted of 49 questions eliciting general information about the firm, its business operations, its economic and competition situation, its R\&D activities, as well as its cooperation and networking. Firms also provided information about its production capacity and the importance and quality of several different locational factors, including proximity to universities, regional availability of skilled labour, and different types of support provided by regional authorities and institutions. It should be noted that locational conditions improved significantly in many East German regions over the last 15 years, but there is still a strong heterogeneity among regions (Fritsch et al. 2007). Given 
this variation of locational conditions for forms in our sample, these data are suitable for testing locational effects.

SMEs affiliated with a firm group operate with different terms and conditions than independent SMEs. Indeed, companies belonging to a corporate group can exchange resources and competences, as well as share costs and risks associated with internationalization. In addition, it is unclear how much decision-making power these companies have with regard to market strategy and business development, as the organizational structures of the corporate groups to which these firms belong are unknown. Therefore, to avoid the potential bias of affiliation with a firm group, firms that were related to a firm group in 2002 and did not relocate their production or another unit abroad in 2003/2004 are excluded from the analysis. Observations with missing values and data on service-sector companies are also removed, leaving a final sample of 3,075 independent East German firms in the manufacturing sector. Approximately 35 and 2.8 per cent of these firms engaged in exporting and relocated selected business activities abroad in 2003/2004, respectively; about 65 per cent operated in domestic markets only during 2003/2004.

As always when using samples for the analysis, one might be concerned about the representativeness of the used dataset. For this reason, we compared the results regarding international activities of East German SMEs with the findings from other studies according to the size categories (see Table 4 in Appendix). Even though the data used in the comparison are shaped by varying structural factors and refer to alternate size categories, other studies concerned with internationalization yield similar results to the DIW survey of East German manufacturing SMEs. There are larger differences between surveys, however, regarding the relocations abroad. This could be because the comparison data also includes affiliated companies or that —as it is the case in the survey data from the Fraunhofer Institute's 2006 German Manufacturing Survey_-larger companies are overrepresented in the sample (Kinkel et al. 2009). 


\section{Econometric model: dependent and independent variables}

In our analysis setting, each firm has two choices with respect to internationalization in 2003/2004: (1) to engage in exporting; and/or (2) to relocate production and/or other business operations abroad. Thus, we consider two dependent variables: Let $E X$ represent the exporting strategy choice, where $E X=1$ if a firm sells on the foreign markets and $E X=0$ if the firm has domestic sales only. Another dependent variable $R$ takes the value 1 if the firm relocates abroad and 0 if the firm does not relocate abroad. Because both dependent variables are binary choice variables, we fit the data to two probit regression models. ${ }^{3}$ The developed econometric models are:

$$
\begin{gathered}
\operatorname{Pr}[E X=1]=\alpha+\beta_{E X} L C+\gamma_{E X} I+\delta_{E X} X+\varepsilon_{E X}, \\
\operatorname{Pr}[R=1]=\alpha+\beta_{R} L C+\gamma_{R} I+\delta_{R} X+\varepsilon_{R},
\end{gathered}
$$

where $L C$ and $I$ refers to locational conditions and firm innovativeness, respectively.

The vector $X$ denotes a set of control variables, described in the next section.

$L C$ : As mentioned before, to account for the influence of firm location on its internationalization, we disentangle it into the effects of various locational conditions. In the model we include the impact of four groups of locational factors: availability of skilled labour; transportation infrastructure; proximity to research facilities; and various types of support from both public authorities and other bodies. The particular locational factors are assessed by firms on a six-point Likert scale, ranging from unimportant (0), important and very bad quality (1), to important and very good quality (5). The variable "skilled labour" refers to the mean value of the firm's assessment of the regional availability of skilled workers and additional education supply. The variable "transportation" measures interregional transportation links. The variable "research facilities" is the mean value of the assessments of

\footnotetext{
${ }^{3}$ As it is possible that firms employ both foreign strategies at the same time, one could suggest that a bivariate probit model might be a more appropriate approach for the empirical analysis in this paper. This approach allows for two binary choice equations with correlated disturbances (e.g., Greene 2003). However, since the estimation results from the binary probit model reveal that the correlation coefficient between the error terms of the two estimation equations turns out to be insignificant, two univariate probit models are more appropriate for this study.
} 
proximity to universities and research institutes. Finally, the variable "support" encompasses assessments of support from local financial institutions, job centres, local authorities, business development corporations, state government, and chambers of industry and commerce.

I: Since firm innovativeness is a complex and multifaceted phenomenon, we include several indicators referring to both inputs and outputs of the innovation process: (1) deployment share in R\&D in 2003 (as a percentage); (2) a dummy for introducing a novel product on the domestic and/or foreign market in 2003/2004; (3) a dummy for applying for a patent in 2003/2004; and (4) a dummy for issuing a license in 2003/2004.

\section{Control variables}

There are several other factors that may influence firm internationalization. First, a firm's probability to engage in foreign activities in $2003 / 2004$ is likely to be affected also by its previous internationalization behaviour. Hence, to account for this we include a dummy for export activity in 2002 as proxy for the past firm international activity. We expect that the past foreign experience increases the probability of internationalization in the next period. Second, due to fact that small firms have fewer resource capacities and higher sensitivity to external barriers than larger ones, we include firm size as another control variable. Firm size should be positively related to its internationalization. Thus, in order to account for the possible nonlinear effects of firm size, the model includes four dummy variables for the following size categories: (1) size $<10$; (2) size $\geq 10$ but $<50$; (3) size $\geq 50$ but $<100$; and (4) size $\geq 100$. Additionally, the model incorporates two variables referring to the frequency of cooperation in product development and sales. These variables are measured on a five-point Likert scale, ranging from we do not cooperate (1), we cooperate sometimes (3), to we often cooperate (5). Accordingly to the network approach, collaboration activities should facilitate internationalization by enhancing firms' core competencies and the specific competitive advantages - by enabling firms to gain access to the complementary resources, competencies, 
and capabilities of their cooperation partners. Finally, the list concludes with the two-digit industry dummies.

\section{Results}

\section{Descriptive analysis}

Table 1 presents the means and standard deviations of the explanatory variables included in the econometric model, as well as the results of t-tests on difference of means for exporting firms and firms relocating selected operations abroad compared to all firms in the sample. Regarding the R\&D and innovation activities, the results reveal that exporting firms exceed the all-SMEs group with all indicators of firm innovative capabilities. Firms relocating selected operations abroad, however, tend to introduce completely novel products and apply for patents more frequently than other firms. In addition, the considered firm groups differ significantly with respect to the assessment of the locational conditions. Both exporting and relocating firms give significantly higher ratings to the interregional transportation conditions. Exporting SMEs gave significantly better assessments of the proximity to research facilities. Interestingly, relocating firms, on average, provide worse assessments of the support from regional authorities and other organizations. Finally, firms operating in foreign markets are significantly different in terms of the past international experience, firm size, cooperation activity and industry.

\section{Insert Table 1 about here}

\section{Model estimation results}

As noted before, in order to test our hypotheses, we estimate two sets of univariate probit models: one for exporting activity and one for selective relocations abroad. Each model set consists of four alternative models including: (1) control variables only, (2) control variables and firm innovativeness indicators, (3) control variables and locational conditions, and (4) all explanatory variables previously mentioned at the same time. 
Table 2 presents the marginal effects and the standard errors for exporting activity of manufacturing East German SMEs from probit models estimations. The four model variants exhibit a comparable and a very high predictive power (the Pseudo- $\mathrm{R}^{2}$ values exceed 0.7 ). This is largely due to the very strong relationship between the past exporting experience and the present exporting activity. ${ }^{4}$ Therefore, to further check the robustness of our results, we estimate the full model but without the dummy variable for the past exporting activity. Model 5 still has a good predictive power (Pseudo- $\mathrm{R}^{2}$ of 0.176 ) and, more importantly, the findings about the factors of our major interest remain largely comparable to those from other model variants.

With respect to SME innovative capabilities, the results reveal that that two out of the three included output-oriented indicators - introducing completely novel products on the market and patent applications - enhance significantly exporting activity of the manufacturing SMEs. Nevertheless, both issuing licenses and R\&D intensity appear to have no impact on SMEs engagement in exporting. Regarding the effects of locational conditions, the findings show that firms giving good assessments of the proximity to universities and other research institutes are more likely to export. Surprisingly, the regional availability of skilled labour is negatively related to the probability to export. Yet, SMEs selling in foreign markets have significantly higher shares of employees with a university degree than nonexporting counterparts. ${ }^{5}$ This could imply that the nonlocal, or extra-regional, labour markets are more important sources of acquiring skilled workers for manufacturing SMEs that export.

\section{Insert Table 2 about here}

The marginal effects and the corresponding standard errors for implementing the strategy of selective relocation abroad by manufacturing SMEs from probit models

\footnotetext{
${ }^{4}$ The Phi correlation coefficient between those dichotomous variables amounts to about 0.89 .

${ }^{5}$ For the exporting and nonexporting firms, the share of employees with a university degree amounts on average to 18.5 and 11.4 per cent, respectively. The difference of these mean values is significant at the 1 per cent level (the corresponding t-value is -8.65).
} 
estimations are shown in Table 3. The full model (i.e., model 4) has good explanatory power (Pseudo- $\mathrm{R}^{2}$ is 0.191 ). Moreover, it is important to note that the results are comparable across the model variants.

As expected, the findings reveal that firms that commit more resources to $R \& D$ are less likely to relocate selected business operations abroad. However, looking at the innovation output side, none of the variables considered impact relocation abroad. With respect to the effects of locational conditions on selective relocations abroad, the results are consistent in both model specifications, i.e., model 3 and 4 . Interestingly, firms that assess the locational conditions - the proximity to research facilities, as well as various types of support from regional authorities and other bodies - as important and high-quality factors are significantly less likely to relocate selected activities abroad. However, having high-quality transportation infrastructure slightly increases the probability of a manufacturer to relocate abroad.

\section{Insert Table 3 about here}

Overall, one should note that the effects of control variables on SMEs international activities are in line with expectations.

\section{Discussion and conclusions}

This paper contributes to the existing literature by providing empirical evidence on the relationships between firm location, innovative capabilities and internationalization. Specifically, this study investigates how various locational conditions as well as both input and output-side indicators of SMEs' innovativeness affect the decision between two considerably different modes of foreign market presence: exporting and relocating selected business operations abroad.

In general, the findings from the empirical analysis provided strong support for our propositions to a large extent. As expected, and as found by several extant studies (e.g., Becchetti and Rossi 2000; Bleaney and Wakelin 2002; Grossman and Helpman 1996; 
Kirchbach and Schmiedeberg 2008; Roper and Love 2002), manufacturing SMEs' engagement in exporting appears to be significantly influenced by the outputs of the innovative activity — introducing completely novel products on the market and by patenting activity. Additionally, the results show that the proximity to research institutions, which facilitates easier and less complicated access to university knowledge, promotes exporting activity by manufacturing SMEs (cf., e.g., Audretsch and Feldman 1996; Beise and Stahl 1999; Mowery and Ziedonis 2001; Zucker et al. 1998).

When it comes to antecedents of selective relocations abroad, as postulated, we find that SMEs with a high degree of R\&D appear to be less likely to separate production from other operating areas and relocate it abroad, than counterparts with little or no R\&D intensity. This is possibly due to the differences in monitoring and transaction costs of production relocated abroad between the knowledge-intensive products and the less-sophisticated and/or simple goods. Indeed, production processes of knowledge-intensive goods clearly involve a higher content of tacit knowledge than those of simple goods. Thus, running the company's 'thinking part' (i.e., R\&D) in the home region, separate from production in foreign locations is associated with higher control costs in the case of knowledge-intensive goods (Anderson and Gatignon 1986; Biggiero 2006; Buckley and Casson 1976; Williamson 1975, 1979). Moreover, consistent with our expectations, manufacturing SMEs that assess the proximity to research facilities, as well as support from various regional authorities and other bodies, as important and high-quality locational factors, exhibit a significantly lower propensity to relocate selected business activities abroad. In fact, by emphasizing the role of the institutional setting - incorporating unique economic, sociological, political and institutional factors - in firm activity, our findings coincide with previous literature focused on innovative milieu, learning regions and/or regional innovation systems (e.g., Asheim and Gertler 2005; Becattini 1990; Campagni 1991; Cooke 2002; Cooke and Morgan 1998). 
Beyond this, our research provided some results that seem to contract our propositions. First, we find that firm R\&D intensity does not significantly impact its likelihood to export, however these results are similar to Becchetti and Rossi (2000), as well as Schlegelmilch and Cooke (1988). Further, other than postulated, the output-side of firm innovation processes does not influence selective relocations abroad. Future research may wish to examine and explain this unexpected result. Finally, we find a significant and negative relationship between the regional availability of skilled labour and SMEs engagement in exporting. This result is opposite of what could be expected, but could imply that rather extraregional or even international labour markets are more important sources skilled staff than the local ones. Indeed, Keeble et al. (1998) provide support for this explanation revealing a significant degree of internationalization of labour market processes, at least for the crucial professional and scientific labour markets.

\section{Implications and limitations}

This paper has important implications for researchers, entrepreneurs and policy-makers, although it has several limitations. First, one potential concern of the study refers to employing firm assessments in the analysis. Indeed, it is true that the data can be biased as it is possible that a firm's assessment of, for instance, locational conditions may not reflect the objective reality of the same (e.g., perceived vs. actual distance from a university or an airport). Nevertheless, the perceptions, regardless of their objective truth, of potential decision makers are of great relevance because these perceptions affect the choices and decisions they ultimately make about the spatial scope of their economic operations (Britton 2004; Oerlemans et al. 2001; Rees and Stafford 1986). In addition, this approach takes into account that not all firms have identical needs and/or requirements regarding locational conditions. In other words, this approach takes firm-specific effects of various locational conditions on its performance into account (Czarnitzki and Hottenroth 2009; Lejpras et al. 2011; Lejpras and Stephan 2011). 
Second, even though many of the explanatory variables included in the model refer to the period prior to implementing international strategies under investigation, the study is still a cross-sectional analysis. This dataset does not allow for the exploration of foreign markets engagement by SMEs over time. Indeed, this research cannot answer interesting questions like, how the internationalization of East-German manufacturing SMEs has changed in the face of the growing integration process of European markets triggered by EU enlargements in 2004 and 2007.

Third, related to the fact above, some of the explanatory variables, especially the firm size control variable, might not be entirely exogenous. For instance, it is widely accepted that larger firms are more likely to export, on the one hand, but, on the other hand, it is possible that exporting activity results in firm growth. Although this paper includes 2002 firm size in explaining SMEs' international behaviour in 2003/2004, it is unclear to what extent 2002 firm size is driven by even earlier export activity.

Entrepreneurs considering or already involved in international expansion might benefit from the results of this paper in several ways. The findings reveal that innovation activity plays a key role in exporting activities by SMEs. Further, manufacturing SMEs conducting R\&D should keep in mind that relocating selected operations abroad implies the widest mobilization of tacit knowledge. Thus, in these cases, the control costs associated with implementing this strategy may be significantly higher than those for firms producing rather simple or unsophisticated goods. Beyond this, firms, especially those operating in a particularly favourable local environment (in terms of a good access to university knowledge and support from regional authorities and other bodies), should take into account that benefiting from the localized capabilities of the foreign region may take some time after relocating selected activities abroad. This is because building up trust-based relationships with local partners and authorities in new locations, as well as developing a similar level of local embeddedness to that in the home region, takes time. 
This research provides also insights into how regional policy-makers can help to boost the presence of SMEs in international markets: Efforts should be made to increase the innovative capabilities of firms by assuring that regional authorities, chambers of industry and commerce, and industry associations undergird the regional economy with assistive services and guidance programmes.

\section{References}

Acs, Z. J., R. Morck, J.M. Shaver, and B. Yeung. 1997. The internationalization of small and medium-sized enterprises: A policy perspective. Small Business Economics 9, no. 1: 7-20.

Alberti, F.G. 2006. The decline of the industrial district of Como: recession, relocation or reconversion? Entrepreneurship and Regional Development 18: 473-501.

Amin, A., and N. Thrift. 1994. Living in the global. In Globalization, Institutions, and Regional Development in Europe, ed. A. Amin and N. Thrift, 1-22. Oxford: Oxford University Press.

Amiti, M. 1998. New trade theories and industrial location in the EU: A survey of the evidence. Oxford Review 14, no. 2: 45-53.

Anderson, E., and H. Gatignon. 1986. Modes of foreign entry: A transaction cost analysis and propositions. Journal of International Business Studies 17, no. 3: 1-26.

Asheim, B.T., and M. Gertler. 2005. The geography of innovation: regional innovation systems. In The Oxford Handbook of Innovation, ed. J. Fagerberg, J. Mowery and R. Nelson, 291-317. Oxford: Oxford University Press.

Audretsch, D.B. 2000. Knowledge, globalization, and regions: an economist's perspective. In Regions, Globalization, and the Knowledge-Based Economy, ed. J.H. Dunning, 42-62. Oxford: Oxford University Press.

Audretsch, D.B., and M.P. Feldman. 1996. R\&D spillovers and the geography of innovation and production. American Economic Review 86, no. 3: 630-40. 
Aydalot, Philippe, and David Keeble. 1988. High technology industry and innovative environments: The European experience. London: Routledge.

Barringer, B., and D. Greening. 1998. Small business growth through geographic expansion: A comparative case study. Journal of Business Venturing 13, no. 6: 467-92.

Barrios, S., H. Görg, and E. Strobl. 2003. Explaining firms’ export behaviour: R\&D, spillovers and the destination market. Oxford Bulletin of Economics and Statistics 65, no. 4: 475-96.

Becattini, G. 1990. The Marshallian industrial district as a socio-economic notion. In Industrial district and inter-firm cooperation in Italy, ed. F. Pyke, G. Becattini, and W. Sengenberger, 37-51. Geneva: International Institute for Labour Studies.

Becchetti, L., and S.P.S. Rossi. 2000. The positive effect of industrial district on the export performance of Italian firms. Review of Industrial Organization 16: 53-68.

Beise, M., and H. Stahl. 1999. Public research and industrial innovations in Germany. Research Policy 28: 397-422.

Bell, J. 1995. The internationalization of small computer software firms: A further challenge to "stage" theories. European Journal of Marketing 29, no. 8: 60-75.

Belso-Martínez, J.A. (2006). Do industrial districts influence export performance and export intensity? Evidence for Spanish SMEs' internationalization process. European Planning Studies 14, no. 6: 791-810.

Benito, G., and L. Welch. 1994. Foreign market servicing: beyond choice of entry mode. Journal of International Marketing 2: 7-27.

Biggiero, L. 2006. Industrial and knowledge relocation strategies under the challenges of globalization and digitalization: the move of small and medium enterprises among territorial systems. Entrepreneurship and Regional Development 18: 443-71.

Blankenburg, D., and J. Johanson. 1992. Managing network connections in international business. Scandinavian International Business Review 1, no. 1: 5-19. 
Bleaney, M., and K. Wakelin. 2002. Efficiency, innovation and exports. Oxford Bulletin of Economics and Statistics 64, no. 3: 3-15.

Britton, J.N.H. 2004. High technology localization and extra-regional networks.

Entrepreneurship and Regional Development 16: 269-390.

Brouwer, E., and A. Kleinknecht. 1996. Determinants of innovation: a micro economic analysis of three alternative output indicators. In Determinants of innovation, the message from new indicators, ed. A.H. Kleinknecht, 99-124. London: Macmillan Press.

Brunninge, O., M. Nordqvist, and J. Wiklund. 2007. Corporate governance and strategic change in SMEs: The effects of ownership, board composition and top management teams. Small Business Economics 29, no. 3: 295-308.

Buckley, P.J. 1988. The limits of explanation: Testing the internalization theory of the multinational enterprise. Journal of International Business Studies 19, no. 2: 181-93.

Buckley, Peter J., and Mark C. Casson. 1976. The future of the multinational enterprise. London: Macmillan.

Cairncross, Frances C. 1997. The death of distance: How the communications revolution is changing our lives. Boston, MA: Harvard Business School.

Campagni, R., ed. 1991. Innovation networks: Spatial perspectives. London: Belhaven Press. Cooke, Philip. 2002. Knowledge economies: Clusters, learning, and cooperative advantage. New York: Routledge.

Cooke, Philip, and Kevin Morgan. 1998. The association economy: firm, regions and innovation. Oxford: Oxford University Press.

Cooper, R.G., and E.J. Kleinschmidt. 1985. The impact of export strategy on export sales performance. Journal on International Business Studies 16: 37-55.

Crouch, C., and C. Trigilia. 2001. Still local economies in global capitalism? In Local Production Systems in Europe: Rise or Demise?, ed. C. Crouch, L. Le Gales, C. Trigilia, and H. Voelzkow, 212-546. Oxford: Oxford University Press. 
Coviello, N.E., and A. McAuley. 1999. Internationalisation and the smaller firm: A review of contemporary empirical research. Management International Review 39, no. 3: 223-56.

Cunningham, M.T., and K. Culligan. 1991. Competitiveness through networks of relationships in information technology product markets. In New perspectives on international marketing, ed. S.J. Paliwoda, 251-75. London: Routledge.

Czarnitzki, D., and H. Hottenrott. 2009. Are local milieus the key to innovation performance? Journal of Regional Science 49, no. 1: 81-112.

Daniels, J.D. 1991. Relevance in international business research: A need for more linkages. Journal of International Business Studies 22, no. 2: 177-86.

deMartino, R., D.M. Reid, and S.C. Zygliodopoulos. 2006. Balancing localization and globalization: exploring the impact of firm internationalization on a regional cluster. Entrepreneurship and Regional Development 18: 1-24.

Doole, Isobel, and Robin Lowe. 1999. International marketing strategy. City: Thomson Learning.

Dunning, John H. 1981. International production and the multinational enterprise. London: Allen \& Unwin.

Dunning, J.H. 1988. The eclectic paradigm of international production: A restatement and some possible extensions. Journal of International Business Studies 19: 1-31.

Dunning, J.H. 1998. Location and the multinational enterprise: A neglected factor? Journal of International Business Studies 29: 45-66.

Eickelpasch, A., and O. Pfirrmann. 2008. Erschließung des Marktpotenzials in den mittel- und osteuropäischen EU-Mitgliedsstaaten durch kleine und mittlere Unternehmen. DIW Berlin Politikberatung kompakt 47.

Enright, M. 1998. Regional clusters and firm strategies. In The dynamic firm. The role of technology, strategy, organization, and regions, ed. A. Chadler, P. Hagström, and Ö. Sölvell, 315-342. New York: Oxford University Press. 
Feldman, M.P. 1999. The new economics of innovation, spillovers and agglomeration: a review of empirical studies. Economics of Innovation and New Technology 8: 5-25.

Fernández-Ortiz, R., and G.F. Lombardo. 2009. Influence of the capacities of top management on the internationalization of SMEs. Entrepreneurship and Regional Development 21, no. 2: 131-54.

Fritsch, Michael, Tobias Hennig, Viktor Slavtchev, and Norbert Steigenberger. 2007. Hochschulen, Innovation, Region: Wissenstransfer im räumlichen Kontext. Berlin: Edition Sigma.

Fujita, Masahisa, Paul Krugman, and Anthony J. Venables. 2001. The spatial economy: cities, regions and international trade. Cambridge, MA: MIT Press.

Gordon, R. 1991. Innovation, industrial networks and high-technology regions. In: Innovation Networks: Spatial Perspectives, ed. R. Campagni, 174-195. London and New York: Belhaven.

Gordon, I., and R. McCann. 2000. Industrial clusters: complexes, agglomeration and/or social networks? Urban Studies 37, no. 3: 513-32.

Granovetter, Mark. 1992. Problems of explanation in economic sociology. Cambridge MA: Harvard Business Scholl Press.

Gray, John. 1998. False Dawn: the delusions of global capitalism. London: Granta Books.

Griliches, Z., ed. 1984. R\&D, patents and productivity. Chicago: University of Chicago Press.

Grossman, G.M., and E. Helpman. 1989. Product Development and International Trade. Journal of Political Economy 97, no. 6: 1261-83.

Hennart, J.-F. 1988. A transaction costs theory of equity joint ventures. Strategic Management Journal 9: 361-374.

Hennart, J.-F. 1991. The transaction costs theory of joint ventures: An empirical study of Japanese subsidiaries in the United States. Management Science 37, no. 4: 483-97. Hollenstein, H. 2005. Determinants of international activities: Are SMEs different? Small 
Business Economics 24: 431-50.

Huggins, R., and A. Johnston. 2010. Knowledge flow and inter-firm networks: The influence of network resources, spatial proximity and firm size. Entrepreneurship and Regional Development 22, no. 5: 457-84.

Ito, K., and V. Pucik. 1993. R\&D spending, domestic competition, and export performance of Japanese manufacturing firms. Strategic Management Journal 14: 61-75.

Jensen, R., and M. Thursby. 2001. Proofs and prototypes for sale: The licensing of university inventions. American Economic Review 91, no. 1: 240-59.

Johanson, J., and L.-G. Mattsson. 1988. Internationalization in industrial systems-A network approach. In Strategies in global competition, ed. N. Hood and J. E. Vahlne, 287-314. New York: Croom Helm.

Johanson, J., and L.-G. Mattsson. 1992. Network positions and strategic action-An analytical framework. In Industrial networks. A new view of reality, ed. B. Axelsson and G. Easton, 206-17. London: Routledge.

Johanson, J., and J.-E. Vahlne. 1990. The mechanism of internationalization. International Marketing Review 7, no. 4: 11-24.

Johanson, J., and J.-E. Vahlne. 1992. Management of foreign market entry. Scandinavian International Business 1, no. 3: 9-27.

Johanson, J., and J.-E. Vahlne. 1977. The internationalization process of the firm-A model of knowledge development and increasing foreign market commitments. Journal of International Business Studies 8: 23-32.

Johanson, J., and F. Wiedersheim-Paul. 1975. The internationalization of the firm-Four Swedish cases. Journal of Management Studies 12, no. October: 305-22.

Keeble, D., C. Lawson, H. Lawton Smith, B. Moore, and F. Wilkinson. 1998. Internationalisation processes, networking and local embeddedness in technologyintensive small firms. Small Business Economics 11: 327-42. 
Kinkel, S., S. Maloca, and A. Jäger. 2009. Produktions- und FuE-Verlagerungen ins Ausland - Verbreitung, Motive und strategische Implikationen für das deutsche Verarbeitende Gewerbe. Stuttgart: Fraunhofer IRB Verlag.

Kirbach, M., and C. Schmiedeberg. 2008. Innovation and export performance: adjustment and remaining differences in East and West German manufacturing. Economics of Innovation and New Technology 17, no. 5: 435-57.

Knight, G.A. 2001. Entrepreneurship and strategy in the international SME. Journal of International Management 7: 155-71.

Krugman, Paul R. 1991. Geography and Trade. Cambridge, MA: MIT Press.

Kuo, H.-C., and Y. Li. 2003. A dynamic decision model of SMEs' FDI. Small Business Economics 20: 219-31.

Lejpras, A., A. Eickelpasch and A. Stephan. 2011. Locational and Internal Sources of Firm Competitive Advantage: Applying Porter's Diamand Model at the Firm Level. Journal of Strategic Management Education 7, no. 2: 1-25.

Lejpras, A., and A. Stephan. 2011. Locational Conditions, Cooperation, and Innovativeness: Evidence from Research and Company Spin-Offs. The Annals of Regional Science, 46(3), 543-575.

Lo, V., C. Hauser, J. Stiebale, D. Engel, and K. Kohlberger. 2007. Internationalisierung des Mittelstandes. In Den Aufschwung festigen—Beschäftigung und Investitionen weiter vorantreiben. Mittelstandsmonitor 2007-Jährlicher Bericht zu Konjunktur- und Strukturfragen kleiner und mittlerer Unternehmen, ed. KfW, Creditreform, IfM, RWI and ZEW. Frankfurt am Main: KfW Bankengruppe.

Lockett, N., F. Cave, R. Kerr, and S. Robinson. 2009. The influence of co-location in higher education institutions on small firms' perspectives of knowledge transfer.

Entrepreneurship and Regional Development 21, no. 3: 265-83.

Longhi, C. 1999. Networks, collective learning and technology development in innovative 
high technology regions: the case of Sophia-Antipolis. Regional Studies 33, no. 4: 33342.

Lösch, A. 1938. The nature of regions. Southern Economic Journal 5, no. 1: 71-8.

Lundvall, Bengt-Åke. 1992. National systems of innovation. London: Pinter.

Marshall, Alfred. (1920). Principles of economics. London: Macmillan.

Martin, R., and P. Sunley. 2002. Deconstructing clusters. Journal of Economic Geography 3: $5-35$.

McDougall, P., and B. Oviatt. 1997. International entrepreneurship literature in the 1990s and direction for future research. In Entrepreneurship 2000 ed. D.L. Sexton and R.W. Smilor, 291-320. Chicago: Upstart Publishing Company.

Meyer, M. 2002. Academic entrepreneurs or entrepreneurial academics? Research-based ventures and public support mechanisms. $R \& D$ Management 33, no. 2: 107-15.

Molina, F.X. 2002. Industrial districts and innovation: the case of the Spanish ceramic tile industry. Entrepreneurship and Regional Development 14: 317-35.

Molina-Morales, F.X., and M.T. Martínez-Fernández. 2006. Industrial districts: something more than a neighbourhood. Entrepreneurship and Regional Development 18: 503-24.

Mowery, D.C., and A.A. Ziedonis. 2001. The geographic reach of market and non-market channels of technology transfer: Comparing citations and licenses of university patents. NBER Working Paper No. 8568.

OECD. 1997. Globalization and Small and Medium Enterprises (SMEs). Paris: OECD.

OECD. 2008. Staying competitive in the global economy: compendium of studies on global value chains. Paris: OECD.

Oerlemans, L.A.G., M.T.H. Meeus, and F.W.M. Boekema. 2001. Firm clustering and innovation: Determinants and effects. Papers in Regional Science 80: 337-56.

O'Farrell, P.N., P.A. Wood, and J. Zheng. 1998. Regional influences on foreign market development by business service companies: Elements of a strategic context explanation. 
Regional Studies 32, no. 1: 31-48.

Oviatt, B., and B. McDougall. 1997. Challenges for internationalisation process theory: The case of international new ventures. Management International Review 37, no. 2: 85-99.

Paniccia, Ivana. (2002). Industrial districts: evolution and competitiveness in Italian firms. Cheltenham: Edward Elgar Publishing.

Punnett, Betty J., and David A. Ricks. 1992. International business. Boston: PWS-Kent Publishing.

Porter, Michael E. 1990. The competitive advantage of nations. New York: Free Press.

Ramírez-Pasillas, M. 2010. International trade fairs as amplifiers of permanent and temporary proximities in clusters. Entrepreneurship and Regional Development 22, no. 2: 155-87.

Rees, J., and H.A. Stafford. 1986. Theories of regional growth and industrial location: Their relevance for understanding high-technology complexes. In Technology, Regions, and Policy, ed. J. Rees, 23-50. New Jersey: Rowman \& Littlefield Publishers.

Rocha, A., B. Kury, and J. Monteiro. 2009. The diffusion of exporting in Brazilian industrial clusters. Entrepreneurship and Regional Development 21, no. 5-6: 529-52.

Root, Franklin R. 1994. Entry strategies for international markets. New York: Lexington Books.

Roper, S., and J.H. Love. 2002. Innovation and export performance: evidence from the UK and German manufacturing plants. Research Policy 31: 1087-102.

Rugman, Alan M. 1981. Inside the multinationals: the economics of internal markets. London: Croom Helm.

Ruzzier, M., B. Antoncic, and R.D. Hisrich. 2007. The internationalization of SMEs: developing and testing a multi-dimensional measure on Slovenian firms. Entrepreneurship and Regional Development 19: 161-83.

Sammarra, A. 2005. Relocation and the international fragmentation of industrial districts value chain: matching local and global perspectives. In Industrial districts, relocation, and 
the governance of the global value chain, ed. F. Belussi and A. Sammarra, 61-70. Padua: CLEUP.

Sammarra, A., and F. Belussi. 2006. Evolution and relocation in fashion-led Italian districts: evidence from two case-studies. Entrepreneurship and Regional Development 18: $543-$ 62.

Schlegelmilch, B.B., and J.N. Crook. 1988. Firm-level determinants of export intensity. Managerial and Decision Economics 9: 291-300.

Sorenson, O., and J.A.C. Baum. 2003. Editor's introduction - geography and strategy: the strategic management of space and place. Advances in Strategic Management 20: 1-19.

Staber, U. 2009. Collective learning in clusters: Mechanisms and biases. Entrepreneurship and Regional Development 21, no. 5-6: 553-73.

Storper, M. 1995a. Competitiveness policy options: the technology-regions connection. Growth and Change 26, no. 2: 285-309.

Storper, M. 1995b. The resurgence of regional economies, ten years later: The region as a nexus of untraded interdependencies. European Urban and Regional Studies 2, no. 3: $191-221$.

Stöhr, W. 1986. Territorial innovation complexes. In Milieux innovateurs en Europe, ed. P. Aydalot, 29-54. London: Routledge.

Swann, P., M. Prevezer, and D. Stout, ed. 1998. The dynamics of industrial clustering: international comparisons in computing and biotechnology. Oxford: Oxford University Press.

Tolstoy, D. 2010. Network development and knowledge creation within the foreign market: A study of international entrepreneurial firms. Entrepreneurship and Regional Development 22, no. 5: 379-402.

Vázquez-Barquero, Antonio. 2002. Endogenous development: Networking, innovation, institutions, and cities. New York: Routledge. 
Weber, Alfred. 1929. Theory of the location of industries. Chicago: the University of Chicago Press.

Williamson, Oliver E. 1975. Markets and hierarchies, analysis and antitrust implications: a study in the economics of internal organization. New York: Free Press.

Williamson, O.E. 1979. Transaction-cost economics: The governance of contractual relations. Journal of Law and Economics 22, no. 2: 233-61.

Wolff, J., and T. Pett. 2000. Internationalisation of small firms: An examination of export competitive patterns, firm size and export performance. Journal of International Business Studies 25, no. 2: 253-72.

Zahra, S.A., and G. George. 2002. International entrepreneurship: the current status of the field and future research agenda. In Strategic Entrepreneurship: Creating a New Mindset, ed. M.A. Hitt, R.D. Ireland, S.M. Camp and D.L. Sexton, 253-88. Oxford: Blackwell Publishers.

Zucker, L., M. Darby, and M. Brewer. 1998. Intellectual human capital and the birth of U.S. biotechnology enterprises. American Economic Review 88, no. 1: 290-306. 


\section{Tables}

Table 1 Descriptive statistics

\begin{tabular}{|c|c|c|c|c|c|c|}
\hline & \multicolumn{2}{|c|}{ Exporting firms } & \multicolumn{2}{|c|}{ Firms relocating abroad } & \multicolumn{2}{|c|}{ All firms } \\
\hline & Mean & SD & Mean & $\mathrm{SD}$ & Mean & $\mathrm{SD}$ \\
\hline Export activity in 2002 (d) & $0.87 * * *$ & 0.34 & $0.74 * * *$ & 0.44 & 0.31 & 0.46 \\
\hline \multicolumn{7}{|l|}{ Firm size in 2002 (in employees) } \\
\hline size $<10(\mathrm{~d})$ & $0.33 * * *$ & 0.47 & $0.25 * * *$ & 0.44 & 0.46 & 0.50 \\
\hline $10<=$ size $<50(\mathrm{~d})$ & $0.49 * *$ & 0.50 & $0.29 * * *$ & 0.46 & 0.45 & 0.50 \\
\hline $50<=$ size $<100(d)$ & $0.11 * * *$ & 0.32 & $0.23 * * *$ & 0.42 & 0.06 & 0.24 \\
\hline size $>=100(d)$ & $0.07 * * *$ & 0.25 & $0.22 * * *$ & 0.42 & 0.03 & 0.18 \\
\hline \multicolumn{7}{|l|}{ Firm innovativeness } \\
\hline R\&D intensity (in \%) & $8.33 * * *$ & 14.39 & 4.55 & 6.98 & 4.79 & 12.31 \\
\hline Introducing novel products (d) & $0.26 * * *$ & 0.44 & $0.25 * *$ & 0.44 & 0.14 & 0.35 \\
\hline Patent applications (d) & $0.18 * * *$ & 0.39 & $0.20 * *$ & 0.40 & 0.09 & 0.28 \\
\hline License issues (d) & $0.02 * *$ & 0.15 & 0.02 & 0.15 & 0.01 & 0.11 \\
\hline \multicolumn{7}{|l|}{ Locational conditions } \\
\hline Skilled labour & 1.57 & 1.32 & 1.50 & 1.18 & 1.61 & 1.32 \\
\hline Research facilities & $0.71 * * *$ & 1.42 & 0.33 & 0.94 & 0.41 & 1.12 \\
\hline Transportation & $1.60 * *$ & 1.78 & $1.85 *$ & 1.86 & 1.46 & 1.78 \\
\hline Support & 1.14 & 1.00 & $0.94 *$ & 0.95 & 1.14 & 0.99 \\
\hline \multicolumn{7}{|l|}{ Cooperation frequency in ... } \\
\hline product development & $2.16 * * *$ & 1.35 & $2.22 * * *$ & 1.37 & 1.75 & 1.20 \\
\hline sales & $1.86 * * *$ & 1.31 & 1.67 & 1.17 & 1.71 & 1.21 \\
\hline \multicolumn{7}{|l|}{ Industry affiliation } \\
\hline $\begin{array}{l}\text { Food products, beverages and } \\
\text { tobacco }(\mathrm{d})\end{array}$ & $0.03 * * *$ & 0.18 & 0.06 & 0.23 & 0.09 & 0.29 \\
\hline $\begin{array}{l}\text { Textiles, textile products, leather } \\
\text { and footwear }(\mathrm{d})\end{array}$ & 0.06 & 0.24 & $0.11 *$ & 0.32 & 0.05 & 0.22 \\
\hline $\begin{array}{l}\text { Wood and product of wood and cork } \\
\text { (d) }\end{array}$ & $0.02 * * *$ & 0.16 & $0.02 *$ & 0.15 & 0.05 & 0.22 \\
\hline $\begin{array}{l}\text { Pulp, paper, paper products, printing } \\
\text { and publishing (d) }\end{array}$ & $0.06 * *$ & 0.24 & 0.05 & 0.21 & 0.08 & 0.28 \\
\hline $\begin{array}{l}\text { Chemicals and chemical products } \\
\text { (d) }\end{array}$ & $0.04 * * *$ & 0.19 & 0.03 & 0.18 & 0.02 & 0.15 \\
\hline Rubber and plastic products (d) & $0.09 * * *$ & 0.28 & 0.06 & 0.23 & 0.06 & 0.23 \\
\hline Rubber and plastic products (d) & $0.03 * * *$ & 0.18 & $0.02 *$ & 0.15 & 0.05 & 0.22 \\
\hline $\begin{array}{l}\text { Basic metals and fabricated metal } \\
\text { products }(d)\end{array}$ & $0.18 * * *$ & 0.38 & 0.18 & 0.39 & 0.24 & 0.43 \\
\hline $\begin{array}{l}\text { Machinery, electrical and optical } \\
\text { equipment }(d)\end{array}$ & $0.38 * * *$ & 0.49 & 0.28 & 0.45 & 0.26 & 0.44 \\
\hline Transport equipment (d) & 0.02 & 0.16 & $0.07 *$ & 0.25 & 0.02 & 0.14 \\
\hline $\begin{array}{l}\text { Manufacturing n.e.c and recycling } \\
\text { (d) }\end{array}$ & 0.07 & 0.26 & 0.11 & 0.32 & 0.07 & 0.25 \\
\hline $\mathrm{N}($ in $\%)$ & 1092 (35.5) & & $(2.8)$ & & 3075 & $(100)$ \\
\hline
\end{tabular}


Table 2 Results for export activity of manufacturing SMEs from probit model estimationMarginal effects and corresponding robust standard errors in parentheses

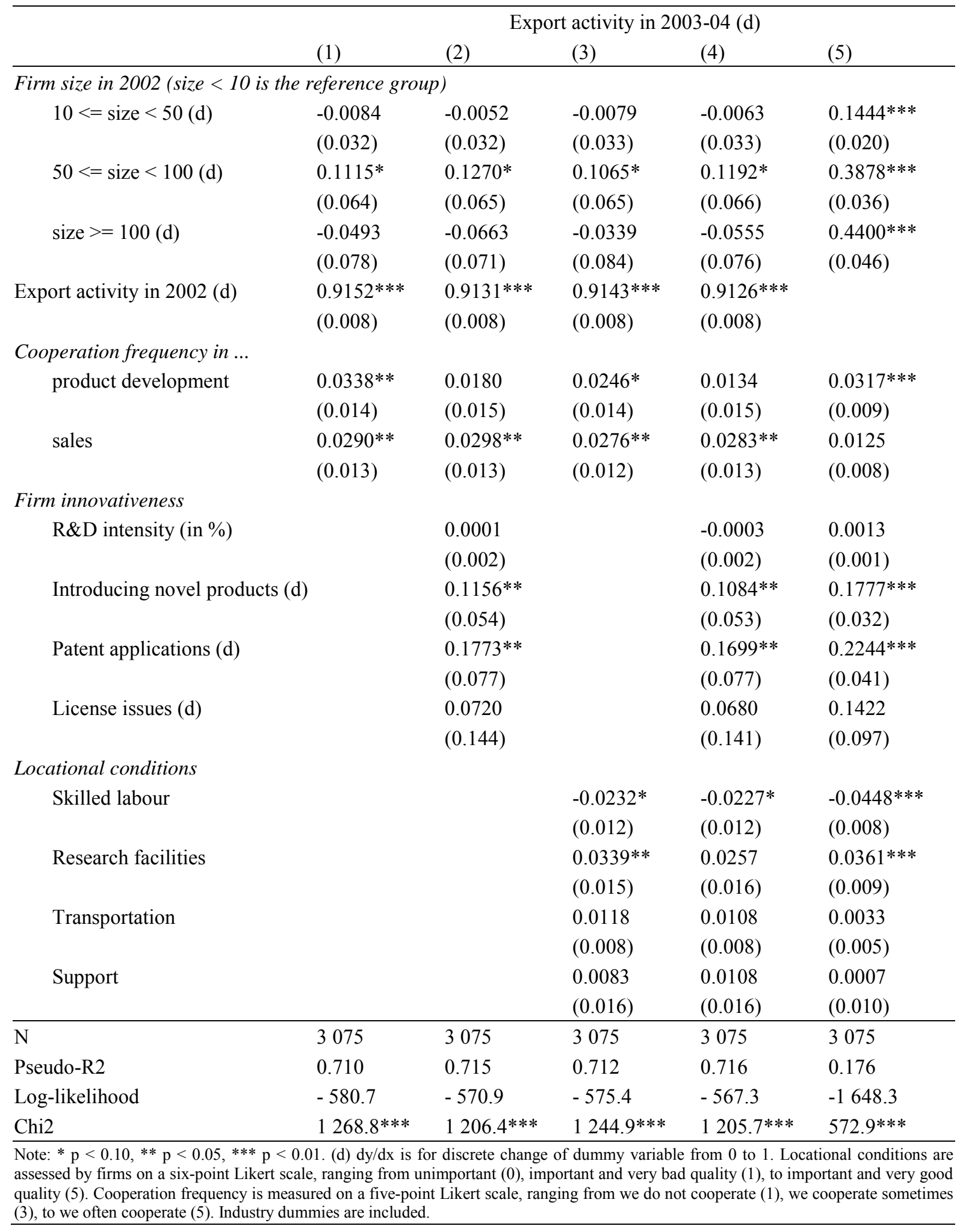


Table 3 Results for selective relocation abroad by manufacturing SMEs from probit model estimation-Marginal effects and corresponding robust standard errors in parentheses

Selective relocation abroad in 2003-04 (d)

Model: (1)

Firm size in 2002 (size $<10$ is the reference group)

$$
\begin{aligned}
& 10<=\operatorname{size}<50(d) \\
& 50<=\operatorname{size}<100(d) \\
& \text { size }>=100(d)
\end{aligned}
$$

Export activity in 2002 (d)

Cooperation frequency in ...

product development

sales

-0.0028
$(0.005)$
$0.0458 * *$
$(0.018)$
$0.0920 * * *$
$(0.033)$
$0.0357 * * *$
$(0.008)$

(2)

(3)

(4)

$\begin{array}{llll}0.0021 & 0.0023 & 0.0029 * & 0.0028^{*} \\ (0.002) & (0.002) & (0.002) & (0.002) \\ -0.0023 & -0.0022 & -0.0023 & -0.0022 \\ (0.002) & (0.002) & (0.002) & (0.002)\end{array}$

$0.0344 * * *$
$-0.0017$

$(0.004)$

$(0.004)$

$0.0463 * * *$

$0.0433 * *$

(0.018)

(0.017)

$0.0994 * * *$

$0.0930 * * *$

(0.036)

(0.035)

$0.0330 * * *$

$0.0315^{* * *}$

(0.008)

(0.007)

Firm innovativeness

R\&D intensity (in \%)

Introducing novel products (d)

Patent applications (d)

License issues (d)

Locational conditions

Skilled labour

Research facilities

Transportation

Support

$-0.0004 * *$
$(0.000)$
0.0082
$(0.008)$
0.0043
$(0.007)$
0.0093
$(0.023)$

$-0.0004 * *$ (0.005) 0.0413 **

(0.017) $0.0831 * * *$

(0.032)

(0.008)

(0.023)

$-0.0003^{*}$

(0.000)

0.0078

(0.007)

0.0032

(0.007)

0.0084

(0.021)

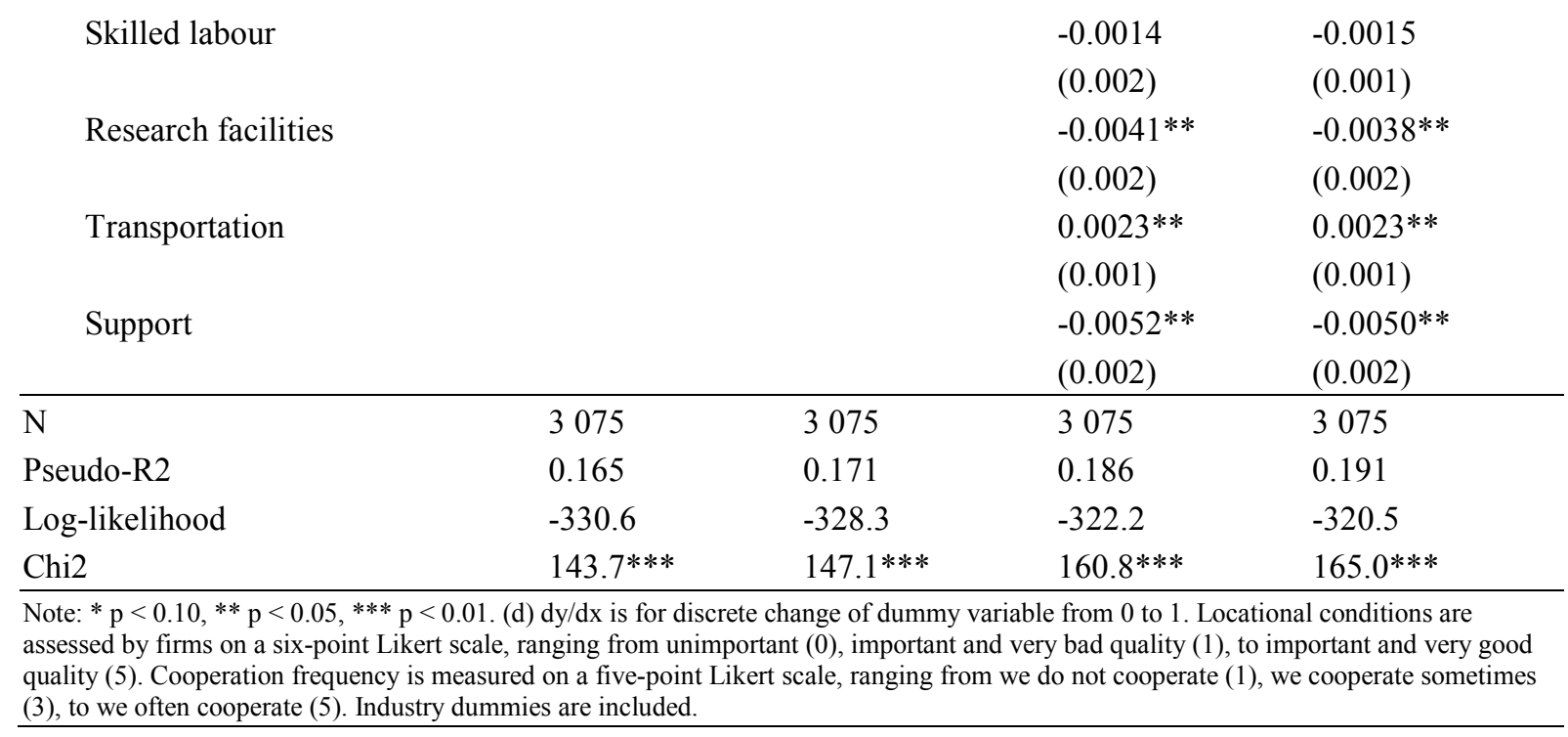




\section{Appendix}

Table 4 Foreign activities of German SMEs in the manufacturing sector according to various studies

\begin{tabular}{lcccc}
\hline & $\begin{array}{c}\text { East German } \\
\text { SMEs }^{1}\end{array}$ & $\begin{array}{c}\text { IAB } \\
\text { establishments } \\
\text { panel 2003 }\end{array}$ & $\begin{array}{c}\text { Deutsche } \\
\text { Bundesbank } \\
2005^{3}\end{array}$ & $\begin{array}{c}\text { German } \\
\text { Manufacturing } \\
\text { Survey 2006 }\end{array}$ \\
\hline Exporting firms & 35.5 & 35.0 & - & - \\
size $<10$ & 25.8 & 19.0 & - & - \\
$10<=$ size $<50$ & 38.9 & 38.0 & - & - \\
$50<=$ size $<100$ & 64.6 & 37.0 & - & - \\
$100<=$ size $<250$ & 67.8 & 47.0 & - & - \\
$250<=$ size $<500$ & 84.6 & 56.0 & - & - \\
size $>=500$ & 2.8 & 64.0 & - & - \\
Firms relocating abroad & 1.6 & - & 4.3 & $10.0^{5}$ \\
size $<10$ & 1.8 & - & 4.7 & 22.0 \\
$10<=$ size $<50$ & 10.6 & - & 15.5 & 46.0 \\
$50<=$ size $<100$ & 16.7 & - & 75.7 & - \\
$100<=$ size $<250$ & 30.8 & - & & \\
$250<=$ size $<500$ & & & &
\end{tabular}

